\title{
HELDER, Herberto. Cobra. In: HELDER, Herberto. Ou o poema contínuo. Lisboa: Assírio \& Alvim, 2004.
}

Gustavo Silveira Ribeiro Universidade Federal de Minas Gerais

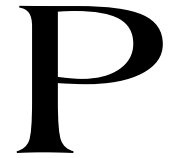

elo menos em tese, só um poeta seria capaz de falar sobre outro poeta. A linguagem pretensamente objetiva da crítica literária tradicional que confesso, humilde, ser a minha única forma possível de expressão - é o contrário da poesia. No caso de um escritor pouco preocupado com a comunicação, como o português Herberto Helder, de quem se pode dizer que cada verso é uma investigação dos limites do sujeito e da linguagem, chega a ser uma espécie de crime tentar qualquer palavra. A beleza de sua poesia está no ponto cego da língua, naquele espaço onde tudo vive precariamente, onde ordem e sentido são quase impossíveis. Diante disso, o que se impõe a mim nesta resenha não é aspirar a elucidação de um poema, nem muito menos realizar sua paráfrase; a tarefa possível, e que pretendo realizar, é observar alguns fragmentos da obra, contornar-lhes a forma com outro texto que os penetre de forma mínima, propondo com isso modos de leitura que não esgotam nem completam os poemas, mas que antes testemunham uma admiração que busca vorazmente compreender o objeto que a fascina, mesmo que não haja esperança alguma de recompensa.

Cobra (1975-76), livro de poemas de Helder, ocupa uma posição singular dentro da singularíssima obra de seu autor. Os versos longos e de sentido rarefeito, as imagens sofisticadas e o tom meditativo dos poemas são os mesmos que se encontram em seus demais escritos. O que torna Cobra, no entanto, um conjunto de poemas particular é a 
profunda unidade do livro, elemento nem sempre tão presente em obras como A colher na boca, sua estréia poética, ou em Do mundo, um de seus últimos trabalhos, ambos bastante extensos e tematicamente mais variados.

Composto por 13 poemas não titulados, separados apenas pelo espaço branco das páginas, o volume vai acumulando significantes que se completam, imagens contínuas que se repetem de poema para poema e que conferem ao texto um caráter circular bastante perceptível, apesar da aparência caótica que ele paradoxalmente apresenta, uma vez que o hermetismo da obra sugere antes desorganização que harmonia. A repetição e a circularidade, se não são recursos propriamente novos na obra de Herberto Helder, nesse livro adquirem importância decisiva, pois servem como possíveis vias de acesso para a construção de sentidos para os poemas.

O universo apresentado em Cobra é como um ciclo, no qual as coisas "fluem e refluem"1 continuamente. O mencionado caráter circular dos poemas se faz presente nas freqüentes repetições de palavras como "ouro", "rosa" e "noite", por exemplo, mas principalmente se dá a ver pelas idéias que certos significantes vão evocando. A referência constante às estações do ano ("E então vinha a baforada do estio"; "Também se enredava o outono nos pulmões da casa"; "O inverno fazia um remoinho nas câmaras"; "Um dia era redonda a primavera" [...]), aos movimentos e fases da lua, ao ato sexual e à alternância contínua entre vida e morte sugerem ao leitor mais atento uma insistência em imagens cíclicas. O fluxo ininterrupto do mundo, que se renova e destrói a cada instante, parece estar sendo representado pelo poeta através de suas escolhas formais e temáticas. Se for possível extrair de Cobra uma significação coerente, creio que o livro pode ser interpretado como uma complexa meditação sobre o tempo. A contemplação das

\footnotetext{
${ }^{1}$ HELDER, 2004, p. 306.Como o próprio nome da coletânea sugere, os poemas de Herberto Helder estão sempre em movimento, modificando-se de edição para edição; por isso, a indicação precisa da data em que essa versão de Cobra foi publicada é importante. Futuramente, ninguém sabe ao certo, é possível que o objeto deste texto nem exista mais, pelo menos na forma atual em que o conhecemos.
}

${ }^{2}$ HELDER, 2004, p. 305. 
imagens recuperadas ao longo dos poemas coloca de modo cons-tante a questão do decurso temporal: seja na percepção fragmentada de um hipotético indivíduo que revê flashes de sua infância, seja através de uma interação cósmica entre o homem e o universo - ambos existindo segundo uma mesma força constante de destruição/ renovação -, é a questão do tempo o que parece estar no centro do livro. Daí, por exemplo, a menção constante ao sexo, visto como momento de dissolução dos limites do sujeito (no mais exato significado erótico) e como possibilidade de morte ou renovação: a perpetuação/degradação da vida como problema. Daí, também, ser possível ver no título do volume uma referência a um animal ambíguo: para muitas culturas a cobra é símbolo de fertilidade e vida, além de ter a forma fálica por excelência, mas para outras não é mais que a recordação da queda e da finitude. ${ }^{3} \mathrm{O}$ oitavo poema do livro, iniciado com os versos "Ele queria coar na cabeça da mulher aprofundada/ uma labareda [...] / Tocava-lhe abismadamente o rosto direto, o sexo/ de ouro bivalve, a jóia do ânus aberto/ - negra garganta de uma camélia baixando" " pode ser analisado com proveito para a interpretação que proponho. Nele, o ato sexual ganha relevância e passa a servir como índice de leitura para várias outras metáforas espalhadas ao longo de Cobra. A idéia da ligação, do contato entre realidades distintas, é óbvia nas imagens que apontam para o sexo, e se faz notável também nos insistentes significantes "pulmões", "boca", "cúspide", "garganta" e "ventosas", todos sugerindo comunicação entre interior e exterior, assim como as imagens do "pênis" e do "ânus" dão a entender. O já referido tom meditativo do livro, que se concentra, como penso, no problema do tempo, ganha uma nova dimensão: a reflexão sobre o devir não é apenas individual, mas integra uma perspectiva totalizante, quase metafísica. O ser, na poesia

\footnotetext{
${ }^{3}$ Para os cristãos, a cobra (ou, mais comumente, a serpente) é índice do pecado e da morte. No entanto, para muitos povos primitivos o animal simboliza a força da vida, uma vez que é conhecida sua capacidade de sobrevivência e de renovação. A troca periódica de peles a que o bicho recorre certamente está associada a isso, além da sua própria anatomia, que como já disse tem a forma do falo.
}

${ }^{4}$ HELDER, 2004, p. 321. 
de Helder, nunca está só: apenas em comunhão universal ele de fato existe. O tempo, para ele, é agente das metamorfoses que a todos atingem, sem diferenças. Assim, o poeta propõe, com seu habitual hermetismo, uma leitura do mundo como palco da transformação incessante. Curioso é notar que isso nem sempre é visto sem terror.

Ao refletir sobre a transformação, sobre o fluxo contínuo do estar-no-mundo, Herberto Helder não confere positividade ou mesmo se mostra indiferente a esse fenômeno. O sistema imagético que os poemas desenham está marcado por vocábulos de conotação negativa, vocábulos esses associados à consciência de que o devir implica, inevitavelmente, em destruição, muito embora o poeta demonstre saber que destruir é a outra face do ato de criar. Inúmeros são os versos que atestam o horror da finitude do corpo e do mundo em Cobra. "Deus caça-me com uma lança radiosa", "A minha idade escapa-se de um lado para o outro" e, principalmente, "Todos os dias faço uma idade bubônica" são momentos em que os poemas ganham intensidade e as reflexões propostas pelo poeta nos interstícios de seus versos apresentam um outro tema importante no livro: o medo.

Chamado de "favo cerebral", o medo surge em Cobra como consciência do devir. É claro que se pode argumentar que numa poesia que tende à despersonalização, à abolição do sujeito, como é a de Herberto Helder, é difícil falar em consciência, pois ela é inevitavelmente produto de um sujeito minimamente organizado. Mas, a fim de corroborar a interpretação que proponho para o livro, resgato a noção de unidade que identifico em Cobra. Mesmo que não se possa falar aqui num sujeito cartesiano, uno, que expresse sentimentos ou professe verdades ao longo dos poemas, é possível notar a constância com que determinados versos e palavras são utilizados, dando ao volume uma coerência formal e conteudística forte. Tal coerência vai se conformando numa voz, numa persona lírica que se vai mostrando em todo o volume, o que autoriza uma interpretação mais aguda e unificadora do livro. 